\title{
Challenges and Prospects of Foreign Real Estate Investors in Ethiopia
}

\author{
Simachew Mulugeta \\ Lecturer, Dire Dawa University \\ Research Scholar, Addis Ababa University
}

\begin{abstract}
Housing is a significant issue in determining a country's development both in developing and developed states both in the urban as well as rural areas. Housing can be considered as both economic and social responsibilities of safeguarding members of a society have a home to live in. Among different policies and strategies developed by government the Urban Development Policy and the Plan for Accelerated and Sustainable Development to End Poverty (PASDEP) strategy, have the objectives of encouraging the role of urban areas in the overall national development. To address the basic research objectives a cross sectional survey design using qualitative methodologies of data collection were employed. Finally, Among different challenges that affect foreign real estate developers faced in their investment activities were Legal challenges that foreign real estate investors faced is there is no legally designed regulation in Ethiopia, institutional challenges related to the institutional arrangement and institutional support for investors Finance related challenges i.e. access to finance and poor housing financial institution in the state, Labor related problems even if there is large number of unskilled labor it is very difficult to get skilled professionals, Priority of the investment area real estate investment is not highly encouraged by the government of Ethiopia. This discourages the investors because different incentives that will be given to different foreign investors in other sector were not allowed.
\end{abstract}

Keywords: challenges, prospects, real estaes

\section{Introduction}

Housing is a significant issue in determining a country's development both in developing and developed states both in the urban as well as rural areas. Housing can be considered as both economic and social responsibilities of safeguarding members of a society have a home to live in. Housing is a major part of a nation's wealth, and plays a major role in economic development (Aluko, 2004) and creating sustainable development. As briefly articulated by UN- Habitat (2012), housing is one of those basic social conditions that determine the quality of life and welfare of people and places. This shows that housing is a critical asset demanded by the people and also it is a very important requirement for the expansion of urbanization.

Among different policies and strategies developed by government the Urban Development Policy and the Plan for Accelerated and Sustainable Development to End Poverty (PASDEP) strategy, have the objectives of encouraging the role of urban areas in the overall national development. The policy and the strategy are further articulated in the IntegratedHousing Development Programme (IHDP)(Mathewos Asfaw, 2011). But even if special attention is given to low cost housing; there are also real estate developers whose target is supplying house for the rich people. As it is clearly articulated by Jose camilo otalora Castro (2008) Real estate investment is becoming international issue due to the contribution of real estate to solve housing supply problem in the urban areas. Additionally; the existence of rapid urbanization in different states including in Ethiopia attracts foreign estate development.Here the researcher is interested to conduct a study the challenges and prospects of foreign real estate developers in Ethiopia by taking samples from city administration of Addis Ababa.

\section{Statement of the Problem}

Ethiopia is among the world's fast urbanizing countries. In recent years urbanization has attained unparalleledlevels of growth with the development and expansion of Addis Ababa and other cities (Mathewos asfaw, 2011).Even though, there are different social and economic problems in urbanization, housing shortage in developing countries has escalated to unprecedented rates making the percentage of slum dwellers that reside illegally in a place without authorization and property rights extremely high (UNFPA, 2007). This informal expansion demands the establishment of formal housing system in Ethiopia that includes real estate development and integrated housing development program (depending of the affordability of the people)Real Estate Development is supposed to facilitate housing delivery for the various categories of people. However, the establishment of real estate has influenced changes in land values, which has not positively impacted on some sections of the community especially the low-income earners who cannot afford to meet the market values of either a serviced plot or shell house in these estates. This makes the delivery and accessibility to land very difficult for the majority of the people. In an attempt to acquire big chunks of land, real estate developers entice land owners to sell them big pieces of land. This deprives the sellers of owning the land and in most cases not sharing the established services. (Nakatudde Ruth, 2004)

The real estate sector has been one of the fastest growing segments of the Ethiopian economy. The residential real estate market in Addis Ababa is evolving into a varied mix of extensive government-built condominiums (apparently for lower-income groups), mid-market developments by housing cooperatives, and largely high-end homes built by real estate developers and/or homeowners themselves.Mostly real estate developers operate only for high-income groups as there is little incentive to construct

Volume 6 Issue 12, December 2017 


\section{International Journal of Science and Research (IJSR) \\ ISSN (Online): 2319-7064}

Index Copernicus Value (2016): 79.57 | Impact Factor (2015): 6.391

low-income housing. But still there is large demand of housing in Addis Ababa. For example the number of people close to one million is registered for housing supplied by the government. Thus, it is critically important to undertake a research on challenges and prospects of foreign real estate developers. This study primarily focuses on achieving the following basic/research objectives.

\subsection{Objective of the study}

1) To assess the opportunities of foreign real estate developers

2) To identify the factors that affect foreign real estate investors in Ethiopia

\subsection{Significance of the study}

This study will have the following significance:

It will provide the investors informing the basic challenges and opportunity of real estate developers in Ethiopia. And the manager/policy maker will take the result as an intervention to overcome the problems encountered by the developers. And the user of this information especial the investment agency will use the result of the study to create conducive environment for the investors. It will provide information to the real estate investors regarding the challenges and opportunities of foreign real estate developers in Ethiopia. And it will provide an initiation to overcome the problems they encountered in Ethiopia. In addition the results of the study provide additional input of ideas to concerned bodies or individuals who have an interest to deal on these issues.

\subsection{Methodology of the Study}

The study was based on a cross sectional survey design using qualitative methodologies of data collection. To undertake this study and to collect the relevant data for the study, the researcher took both primary and secondary data into account.

The method that the researcher used to collect the relevant data was as follows: The primary data were collected from the investor representatives using structured and phone interview. And the researcher will prepare interview schedule to record the responses appropriately. In addition to the interview the researcher used the secondary data gathered from the organizations records and reports which are concerned with challenges and opportunities of real estate developers. The researcher used secondary data to triangulate the data collected by interview.Lastly to analyze the data the researcher usesboth qualitative analysis techniques. The collected data was arranged and analyzed accordingly. For the qualitative analysis logical data analysis will be used as of necessary. And the data was presented on the basis of the narration made by the researcher.

\section{Analysis and Discussion}

\subsection{Challenges of real estate investors}

Legal challenges that foreign real estate investors faced: Most of the respondents on their interview clearly stated the basic challenges that they faced as investor in the sector and the basic challenge that they faced during their investment is non-existence of legal frame work (there is no regulatory framework for real estate investors). In addition to this lack of policy support to provide incentives to the private sector for the construction of dwelling units to lower income groups; The complex and bureaucratic transfer procedure of land users increased transaction costs; The cost of transferring land title is too high Lack of clarity of the current construction permit system; The building regulation lacks clarity; The bank loan collaterized by real estate is not fair and Lack of clarity of the current construction permit system. In line with the above stated problems the interview from the investment officer supports the responses of the investors and they justify that there was no clear legal frame work that supports or facilitates the sector. And they stated that when the investors came with different problems that they encounter, it is very difficult to provide a solution due to lack of clearly stated policies regarding foreign real estate investment.

Institutional challenges of foreign real estate investors: As clearly stated by the respondents the Ethiopian government was providing more emphasis for foreign real estate investors. This was directly reflected by establishing the Ethiopian Investment Authority (EIA) to promote, coordinate and facilitate foreign investment in the country. But as stated by the respondent's even if there is good treatment and motivation in the investment office regarding providing all the necessary information required by foreign investors. $\square$ additionally they stated that on the following issues the investment agency took more time and imprecise activities were performed by the investment office on the issues Approving foreign investment applications and issuing investment permits; providing registration services to newly incorporated business organizations; and Issuing trade and operating licenses for foreign investments. This must be improved to motivate the investors to invest in the sector. And the respondents stated that the investment office were poor in Monitoring the implantation of licensed investment projects.And the response from the investment office stated that the stated problems were not totally solved but we are in a position to solve and accelerate the services by conducting different capacity building activities and also by increasing the number of employees to conduct different activities by the agency.

Finance related challenges::The respondents replied that in comparison to other states that their investment was existed the financial problems were existed in Ethiopia. Among the different problems that were related to finance were: There is poor access to credit in Ethiopia in comparison to other areas. There is no alternative financing institutions and there is no appropriately organized financial institution that provides of housing financing industry. 


\section{International Journal of Science and Research (IJSR) \\ ISSN (Online): 2319-7064}

Index Copernicus Value (2016): 79.57 | Impact Factor (2015): 6.391

Labor related problems: As indicated in different literature one of the motivating factors that motivate FDI is availability of skilled, semiskilled and unskilled labor in the hosting country. But the respondents replied that Ethiopia is rich in unskilled labor i.e the investors easily got unskilled labor at cheap price. But they state that they faced problems in getting skilled manpower that perform different professional activities. And the respondents stated that majority of the Ethiopian employees in the real estate investment were unskilled in comparison to skilled labors.

Priority of the investment area: In comparison to other investment sector the real estate investment were not encouraged by the government of Ethiopia. Due to this reason different incentives that were given to different foreign investors were not given to real estate investors. For example investors in other sectors import different materials used for their investment without paying tax.

\subsection{Observed opportunities}

Opportunities in Ethiopia Real Estate Market: Though real estate is a sector with the smallest market barriers and shares in our country Ethiopia, it is still benefit a lot for the aboard investors and professionals to explore their business in Ethiopia due to the following stated opportunities that the investor will earn. Because modern construction is new and there is no availability of local professionals.

Opportunities for real estate related professionals: As we all know that the real estate related professions include urban planner, architect, landscape architect, engineer, project managers, surveyor, real estate appraisers and brokers, real estate investment analyst, and so on. The professional were the principal beneficial through the existence of real estate investment. Along with Ethiopian real estate market becoming a part of the international market, there will be more and more market space for aboard professionals in Ethiopia. But it may require great effort to be successful in by cooperating their efforts to make it localize.

Opportunities for real estate financial service providers: As it is clearly known that the principal sources of income for financial institution is earned through borrowing. It is an urgent issue to develop the real estate capital market through real estate finance innovation. Though there is a strong need from commercial banks to secure their mortgage debt in order to diversify the long term financial risk. Besides, the fact of insufficiency in legal investment channels for institutional investors leads to the inefficiency and high risk for both investors and developers. Therefore, the real estate financial service providers will have bright prospects in assisting Ethiopia to build up real estate financing infrastructure, to innovate real estate service products, to develop advanced mechanism and instruments for controlling of the related financial risk. In addition, the developing commercial property market and rental housing market also provide attractive potentials for institutional investors to participate.

Opportunities for suppliers of construction materials: As the respondents were also requested regarding the construction materials that they used in their investment weather the used all imported Mostly, Imported, Half Imported/Half local and Mostly used locally produced and all local. And respondents agreed that mostly they used locally produced construction materials but some of the materials were imports from the available areas by taking different advantages in to considerations. This will create motivation for different investors to invest in preparation of construction materials and different steal and cement factories.

Opportunities of real estate investors: The following are the demand related opportunities that the foreign real estate developers enjoy by investing in Ethiopia. The issues were categorized as the Increase of Housing Affordability; The Changing of Housing Consumption and The Accelerated Process of Urbanization as the main factors that the investor taken into consideration related to the sector.Such as the increase of Housing affordability; The Changing of Housing Consumption;

The Accelerated Process of Urbanization and Labour market

\section{Conclusions}

The major conclusions of the research were given as follows:

1) Among the different motivating factors that initiate the investors to invest in the area of real estate in Ethiopia were principally availability of cheap and young labor, excess demand of house due to rapid urbanization and increasing of per-capita income due to rapid economic growth recorded in the state, availability of raw material especially land, suitable business place in comparison to other African countries.

2) Among different challenges that affect foreign real estate developers faced in their investment activities were Legal challenges that foreign real estate investors faced is there is no legally designed regulation in Ethiopia, institutional challenges related to the institutional arrangement and institutional support for investors Finance related challenges i.e. access to finance and poor housing financial institution in the state, Labor related problems even if there is large number of unskilled labor it is very difficult to get skilled professionals, Priority of the investment area real estate investment is not highly encouraged by the government of Ethiopia. This discourages the investors because different incentives that will be given to different foreign investors in other sector were not allowed.

3) Of the different opportunities that the different stakeholders got are: Opportunities for real estate related professionals, Opportunities for real estate financial service providers and institutional investors, Opportunities for suppliers of construction materials, and for homebuilders with advanced building technology.

4) The investors also have got an opportunity by investing in Ethiopia and the issues were categorized as the Increase of Housing Affordability; The Changing of Housing Consumption and The Accelerated Process of Urbanization and availability cheap labor as the main factors that the investor taken into consideration related to the sector.

\section{Volume 6 Issue 12, December 2017}




\section{International Journal of Science and Research (IJSR) \\ ISSN (Online): 2319-7064}

Index Copernicus Value (2016): 79.57 | Impact Factor (2015): 6.391

\section{Recommendation}

1) A number of challenges lie ahead of foreign real estate developers but the basic reasons that this problems will be existed are due to lack of regulatory framework that govern the foreign real estate developers. Therefore the researcher suggests that regulatory framework must be prepared to make the sector more successful and to attract other investors from different countries of the world.

2) Housing problem is among the basic social service that the people in Ethiopia faced but in comparison to other investment sector those investors interested to invest in the sector were not encouraged by the government. But the researcher suggests that the sector will minimize the housing problem of one class of the society. Therefore the government must provide different incentive in accordance with the priority.

3) Among the different problems stated in the analysis part weak house financing is the major problem. So the government must conduct different capacity building activities to the financial institutions. And make them the major actors in the investment process.

\section{References}

[1] Agodo, Oriye (1975). The Determinants of U.S. Private Manufacturing Investment in Africa

[2] Asiedu, Elizabeth. (2002). "On the Determinants of Foreign Direct Investment to Developing Countries: Is Africa Different?"

[3] Bende-Nabende, A. (2000). "Foreign direct investment determinants in Sub-Sahara Africa: A cointegration analysis",

[4] Lee, Jim (2003). Cross-Country Evidence on the Effectiveness of Foreign Investment Policies,

[5] Lemi, Adugna and Asefa, Sisay. (2001). Foreign Direct Investment and Uncertainty

[6] Mathewos Asfaw. (2011). Assessment of urban development practices on business expansion in Ethiopia

[7] Morisset Jacques. (2000). "Foreign Direct Investment in Africa

[8] Nakatudde Ruth. (2004). Real estate development, land tenure and land value dynamics in the urban areas of greater Kampala city

[9] Noorbakhsh, F. Paloni, A. and Youssef, A. (2001), "Human Capital and FDI Inflows to Developing countries:

[10] Root, Franklin R. and Ahmed A. (1979). "Empirical Determinants of Manufacturing Direct Foreign Investment in Developing Countries", Economic Development and Cultural Change,

[11] Salisu, Mohammed. (2003). Foreign Direct Investment in Sub-Saharan Africa

[12] Singh, Harinder and Jun, Kwang W. (1995).Some New Evidence on Determinants of Foreign Direct Investment In Developing Countries

[13] Tsikata, G.K, Asante, Yaw and E.M. Gyasi.(2000). Determinants of Foreign Direct Investment in Ghana.

[14] UN-HABITAT. (2012).The Ethiopia Case of Condominium Housing: The Integrated Housing
Development Programme. United Nations Human Settlements Programme: Nairobi.

[15] UNFPA.(2007). State of World Population 2007 Unleashing the potential of Urban Growth. Retrieved November 09, 2010, from United Nations Population Fund:

[16] UNCTAD (1998), World Investment Report: Trends and Determinants. United Nations Conference on Trade and Development.

Volume 6 Issue 12, December 2017

www.ijsr.net

Licensed Under Creative Commons Attribution CC BY 